\title{
Ombudsman's Assessments of Public Administration Conduct:

\author{
Between Legal and Good Administration Norms
}

Milan Remac, Philip M. Langbroek

\section{Introduction}

The proliferation of new designs in solving administrative disputes is a further development in the relation between public law and administration. These "new" alternatives endeavour to compete with the traditional models of pre-trial objection proceedings and trials at administrative tribunals, administrative or ordinary courts. That brings about a slow but gradual change of the role of traditional dispute resolution (especially courts) and alternative dispute resolution (for example ombudsmen ${ }^{1}$, mediation etc.) in cases against the administration. Where courts and tribunals have a prescribed way of public dispute resolution via litigation procedures in public, in mediation, conflict resolutions takes place behind closed doors, in private. $^{2}$

In this article, we deal only with "public services ombudsmen". Ombudsmen that have been created in order to deal with private manners are not covered here. We compare here the way in which ombudsmen in the Netherlands and in England and Wales position normative standards to assess administrative behaviour in relation to the law and to jurisprudence. We have chosen those ombudsmen, because they have in common that they cannot make legally binding decisions and both

1 We use ombudsmen as a plural form of ombudsman. At the same time, this article uses the term ombudsman in the way that it includes not only male but also female holders of the ombudsman office. We believe that use of a word "ombudswoman" or even "ombudsperson" was not an intention of the original creator of this office.

2 There is an ongoing debate about ADR and conflict resolution by courts. This debate has started somewhere with Roscoe Pound, Roscoe Pound, Address Before the American Bar Association Convention (26 August 1906), 35 F.R.D.273 (1964); There are huge libraries on conflict resolution; for this contribution, Meyerson (2005-2006) and Nolan Haly (2005) are of interest. 
evaluate administrative behaviour by exclusively using good administration principles next to legal norms. In this respect, they do differ consistently from the courts. ${ }^{3}$

We do this by focusing on the ombudsmen's way of developing and preserving norms to assess the behaviour of the administration when complained about, and by describing how courts and ombudsmen are related in using the principles of good administration. We will argue that it is possible for ombudsmen to develop and preserve norms of a non-legal character for the assessment of conduct of the administration. This is an expression of their unique constitutional position. While doing so, they contribute to the growth of a body of ethical norms applied by public administration - which we call Ombudsprudence. ${ }^{4}$

First we will describe the ombudsman functions in general, followed by a description of the relations between the law and good-administration principles in the work of the Dutch ombudsmen and in the work of the ombudsmen of England and Wales. We will conclude this essay with a comparative analysis and a summary.

\section{Ombudsman functions}

The ombudsman function can be fulfilled in different ways as the aims of ombudsman work can be defined in different ways. An ombudsman can be qualified as an extra check on public administration. From that perspective, he is a kind of auxiliary component to the checks and balances between the distinct but cooperating state powers. Within that definition, an ombudsman is a supervisor on request, in addition to traditional review mechanisms of the administration.

It is also possible to regard an ombudsman as a guardian of quality performance in public administration. From that perspective, the ombudsman uses (and sometimes also develops) standards that public bodies, office holders and civil servants should live up to. The function of the ombudsman then primarily shows what goes right and what goes wrong in public administration and how the public administration - with a view to those standards - could improve their performance. In this respect, the term "standard" refers to normalisation norms as developed by the International Standards Organisation and the European Foundation for Quality Management in order to evaluate organisational processes and their outcomes and by improving them by means of organisation development (see for example www. iso.org; www.efqm.org). ${ }^{5}$

Another perspective is to see an ombudsman as an addition to legal protection against the government. For all those cases where filing a case in court may

3 For future research, the contribution of the European ombudsman to the development of current norms of good administration can also be involved in a similar comparison: see DeLeeuw (2009).

4 Following the coinage of the term by Langbroek and Rijpkema (2004 and 2006).

5 See for example: www.iso.org; www.efqm.org. 
not solve the problem, an ombudsman can be addressed with a complaint. In this situation, an ombudsman can act as a mediator between the complaining citizen and the public body and civil servants concerned. From that perspective, solving the citizen's problem is the main goal of the ombudsman functioning, regardless if someone has made a mistake.

Last but not least, even though an ombudsman cannot give a binding judgement, in a case of failed mediation or if the ombudsman finds it necessary to inform the administration and the public, he can give an assessment of the lawfulness and the ethical character of the behaviour of the administration. The outcomes of such an ombudsman inquiry can be used as evidence in court proceedings, but they can also be used for organisation development. ${ }^{6}$

\section{The position of Ombudsmen and Courts in dispute resolution}

Dispute resolution is an essential part of the tasks of the state. The rule of law is the result of a development over centuries. It plays also its role in conflict resolution by state bodies, from the monarch to the independent courts. The interest of the state in dispute resolution ${ }^{7}$ and preserving societal stability has made it worthwhile to preserve the results of conflicts and their resolutions by analyses of jurisprudence and by the formulation of clear legal rules. ${ }^{8}$ Codification has been the most farreaching concept of preservation (and adaptation) of legal rules and applied norms in dispute resolution.

During the last few decades of the $19^{\text {th }}$ century and during the $20^{\text {th }}$ century, governments used rule-creation in order to steer societal and technological developments. These rules have become part of a special branch of law - administrative law. Administrative bureaucracies were required to implement those rules in a rational way with a focus on similar decisions in similar cases. The conflicts provoked by these rules had to be resolved by new standards, because the role of the administrative bodies involved in such conflicts between government and individuals and organisations became more dominant as the numbers of administrative decisions grew with the expansion of governmental tasks. Ordinary courts were originally involved in this conflict resolution. ${ }^{9}$ Very often they dealt with such conflicts reluctantly, especially because governmental and other administrative bodies were involved. A specific type

6 For a full inventory of ombudsmen, at least at European context, see Kucsko-Stadlmayer (2008); see also Heede (2000).

7 See, e.g., Finkelstein and Lifshitz 2010, 668: "Traditionally, mediation was regarded as a private, extralegal procedure. Recently, however, legal scholars have partially recognized the state's public responsibility to ensure that mediation proceedings, especially court-annexed mediation, are conducted in a fair and just manner, thus legal regulation of mediation has evolved."

8 As far as they are not instrumental rules for the realisation of government policies.

9 For an early exposé about Courts and Conflict resolution, see Aubert (1967). 
of courts was thus needed, which resulted in the creation of separate administrative courts or in the creation of specific court chambers. Separation of powers also means a separation of responsibilities, also when deciding conflicts between citizens and the administration or between courts and the administration. But even so, the courts have developed norms to assess the behaviour of the state administration. ${ }^{10}$

The question of what type of court should deal with the conflicts between administration and citizens is to be distinguished from the question of how these conflicts should be resolved. In Europe, it is possible to distinguish between countries where ultimately the ordinary courts are responsible for such conflict resolution (e.g. England and Wales, Denmark), countries that have created a system of specialised administrative courts (e.g. France, the Netherlands) and countries with ordinary courts with specialised administrative chambers (e.g. Slovakia, Czech Republic). Another difference is the position and impact of internal and external conflict-resolution mechanisms in the shape of administrative councils, committees or tribunals, within or outside the context of the administration. However, the standards the courts use to control contested administrative decisions or real acts are predominantly statutory (legal) rules and delegated legislation together with so-called principles of proper or good administration (e.g. legality, legitimate expectations, due care, prohibition of abuse of power, motivation, proportionality, reasonableness, fairness etc.). In different countries, similar principles could bear different names. They have in common that they guide the decision-making processes and administrative actions in relation to the citizens and therefore constitute basic norms for administrative behaviour in administration - citizen relations and communication (e.g. Kudrycka 1997; Langbroek 1997).

Dispute resolution by ombudsmen takes a place between internal conflict resolution mechanisms of the administration and external conflict resolution offered by courts. On the one hand, they very often take a position of negotiator between complainants and the administration. On the other hand, they have to make an assessment of the complaint and evaluate the behaviour of the administration. Their evaluation is made by making explicit or implicit reference to the principles that have been developed by the courts to help them judge administrative behaviour in conflicts with citizens (Drewry 2009).

Although some ombudsmen have powers to engage in formal battle with the administration or functionaries within it by starting prosecution or court proceedings (like the Swedish Justitieombudsman), many ombudsmen do not possess such powers. In cases of failed mediation efforts between a complainant and the administration, they can only report the results of their evaluations to representative bodies and publish the reports, containing the assessments in light of the legal rules and/or principles implicitly or explicitly addressed. That is one of the reasons why

10 An important role was and still is played by supreme administrative courts, as for instance the Conseil d'Etat in France. 
ombudsmen should try to express their position in a persuasive way. Development of comprehensive standards and their application in ombudsman assessments of administrative conduct is recommended for each ombudsman. At the same time, their standards should not be developed only formally because they should be used to help ombudsmen persuade administrative bodies and show them what behaviour is required of them based on those norms. However, the normative function of ombudsmen could clash here with the law and with legal standards as developed and/or applied by the courts. The problem here is, of course, that standards used in administrative law by the courts are related to the standards used by ombudsmen. For reasons of legal certainty, it may be considered undesirable that legal norms and norms of good administration grow too much apart as this may make the work of the administration more complicated and also complicate the position of citizens in their relation with the administration.

In the following paragraph, we try to tackle this particular issue in general, and subsequently, we take a closer look at the practice of the Dutch National Ombudsman and the UK Parliamentary Ombudsman.

\section{The relation between the law and ombudsprudence in general}

Norms used by ombudsmen and legal norms can be considered parallel norms that differ in their character. ${ }^{11}$ Good administration, proper administration or even good governance and fairness set the framework of the ombudsman's evaluations. General principles of proper administration refer to the basic norm of the constitutional state, meaning that government should deal with all humans with due care and respect (Rijpkema 2003), similarly as human rights and requirements of propriety when used by the ombudsman. This basic norm expresses the requirement that the government in all its actions should, as far as reasonably possible, support and respect its citizens as autonomous human beings that strife for a meaningful life as they see fit. Just as the general principles of proper administration have been used by the courts to compensate the lack of legal norms for conducting and evaluating public legal acts, general requirements of proper administrative conduct do compensate for the circumstance that representative bodies are not able to control all the acts of the administration (Langbroek and Rijpkema 2004, 18-19). By assessing administrative actions against requirements of proper administrative conduct, ombudsmen legitimise administrative actions. They demonstrate that the governmen-

11 The main goal of mediation is to reach an equitable outcome. An outcome that necessarily fits legal rules is not the most crucial one. See e.g. Gunning (2004), 88. We do not accept that partyacceptability of outcomes of mediation should be the definition of justice in mediation, as Joseph B. Stulberg concludes in Stulberg 2004-2005, 246. This implies that an ombudsman imposes requirements of good administration as standards in order to evaluate administrative conduct and behaviour of citizens. 
tal bodies are bound in all their actions, next to the law and its principles also by some general standards that can be drawn from the sphere that is not necessarily legal. These standards are the general principles of good administrative conduct. The Dutch and English ombudsmen have published many reports assessing complaints and evaluating administrative behaviour. In these reports they have applied requirements of good or proper administration. The result of their work is a large body of their experience of what different requirements of good administration mean in different situations. As ombudsmen work with norms parallel to the legal norms applied by the courts, by analogy with jurisprudence, Langbroek and Rijpkema have created the term Ombudsprudence (Langbroek and Rijpkema 2004, 2006). As such, repositories of ombudsman reports are to be considered warehouses of normative experience with requirements of good or proper administration, just as repositories of jurisprudence are warehouses of normative experience with the law.

The Dutch National Ombudsman and the UK Parliamentary Ombudsman have explicitly accepted the distinction between lawful administrative behaviour and administrative behaviour living up to good-administration norms. Logically, this distinction involves the following combinations of normative assessments of administrative conduct:

\begin{tabular}{|l|l|l|}
\hline Administrative Behaviour & $\begin{array}{l}\text { In accordance with } \\
\text { general standards of } \\
\text { good administration }\end{array}$ & $\begin{array}{l}\text { Not in accordance with } \\
\text { general standards of } \\
\text { good administration }\end{array}$ \\
\hline $\begin{array}{l}\text { In accordance with the } \\
\text { law (Lawful) }\end{array}$ & $\begin{array}{l}\text { Lawful and in accordance } \\
\text { with general standards of } \\
\text { good administration }\end{array}$ & $\begin{array}{l}\text { Lawful but not in accordance } \\
\text { with general standards of } \\
\text { good administration }\end{array}$ \\
\hline $\begin{array}{l}\text { Not in accordance with } \\
\text { the law (Unlawful) }\end{array}$ & $\begin{array}{l}\text { Unlawful but in accordance } \\
\text { with general standards of } \\
\text { good administration }\end{array}$ & $\begin{array}{l}\text { Unlawful and not in } \\
\text { accordance with general } \\
\text { standards of good } \\
\text { administration }\end{array}$ \\
\hline
\end{tabular}

This means that every conduct of the administration can be judged from two different, slightly overlapping and most usually parallel systems; from the point of the law and from the point of view of general standards of good administration. Ombudsmen can sometimes consider both the lawfulness of administrative action and the application of good administrative principles. Sometimes they do not have this opportunity. However, statutory norms of good administration have often been elaborated. For example; time limits for decision-making are an application of the timeliness principle. In the following paragraphs, we describe to what extent this normative quadrant actually applies to the work of Dutch and English ombudsmen.

This general quadrant has to reflect attitudes of the ombudsmen and the scope of their work. It is built upon the Dutch National Ombudsman "Ombudskwadrant" that was created in 2006 (see Annual Report 2007, 16 or Brenninkmeijer 2007), and it represents the ombudsman's vision of generalised types of cases he has encoun- 
tered during the years of his work. This "Ombudskwadrant" is similar to our general scheme though it reflects the Dutch specifics, which is the scope of the National Ombudsman's control - propriety of administrative conduct:

\begin{tabular}{|l|l|l|}
\hline Administrative Behaviour & Proper & Improper \\
\hline Lawful & Lawful and proper & Lawful and improper \\
\hline Unlawful & Unlawful and proper & Unlawful and improper \\
\hline
\end{tabular}

Propriety or, in Dutch, "Behoorlijkheid" is a standard against which Dutch ombudsmen ${ }^{12}$ must assess administrative actions of administrative bodies. ${ }^{13}$ Propriety as such is not defined in the Dutch legislation and it is the ombudsman himself who gives contents to this term. For example, incumbent National Ombudsman Alex Brenninkmeijer sees propriety as an ethical category for the conduct of administrative bodies. (Brenninkmeijer 2007, 60) So even though there is not a legal definition of the notion "propriety", the administrative bodies in the Netherlands have to act in accordance with the law and in accordance with requirements of propriety. Contents of propriety are given in a positive way in the National Ombudsman's set of requirements of proper administration - the Behoorlijkheidswijzer ${ }^{14}$ - and are accessible to all administrative bodies and to individuals. In the following text, we adopt the same perception of propriety as the National Ombudsman. While doing so, we also maintain that "propriety" is a Dutch version of good-administration norms.

The situation in the UK is a bit different. Ombudsmen in the British conditions do not assess the propriety of administrative actions, but instead they search for maladministration in administrative actions. At the same time, the ombudsmen in the UK have not created, at least not expressly, a similar scheme as the Dutch National Ombudsman. Because of that, if we want to apply our general scheme in the conditions of the UK, as well, we need to change some categories in accordance with the scope of ombudsman's control:

\begin{tabular}{|l|l|l|}
\hline Administrative Behaviour & $\begin{array}{l}\text { Without } \\
\text { Maladministration }\end{array}$ & With Maladministration \\
\hline Lawful & $\begin{array}{l}\text { Lawful } \\
\text { withoutmaladministration }\end{array}$ & $\begin{array}{l}\text { Lawful with } \\
\text { maladministration }\end{array}$ \\
\hline Unlawful & $\begin{array}{l}\text { Unlawful conduct without } \\
\text { maladministration }\end{array}$ & $\begin{array}{l}\text { Unlawful conduct with } \\
\text { maladministration }\end{array}$ \\
\hline
\end{tabular}

12 There is not only one ombudsman in the Netherlands as at the level of local government, municipalities and provinces may decide to create their own "ombudsman". The standard of these "local ombudsmen" is also propriety - "behoorlijkheid". See Article 9:17 b) of the General Administrative Law Act.

13 In accordance with Article 9:27 (1) of the General Administrative Law Act.

14 See the Internet page of the National Ombudsman at www.nationaleombudsman.nl/ informatiemateriaal, accessed on 24 August 2011. 
After a close inspection of the scopes of the ombudsmen in the Netherlands and the ombudsmen in the UK, we argue that proper conduct and conduct without maladministration have similarities as both are reflections of a broader category good administration. Because of that, we will apply our broader and more general scheme.

Both in the Netherlands and in the UK, ombudsmen play their roles of complaint handlers, mediators and evaluators of administrative behaviour and in different ways.

For example, the former Ombudsman of Rotterdam, Michiel van Kinderen, used to stress his function as problem solver for complainants but also directed his efforts at improving the functioning of municipal services in their relation with citizens. The Ombudsman of Utrecht stresses her function as a mediator (Gemeentelijke ombudsman Utrecht 2006, 32-35; Gemeentelijke ombudsman Rotterdam 2005 and 2006, especially 3-4). The Dutch National Ombudsman underlines the aspects of mediation and the quality-assessment institute. But next to the issue of the propriety of the administrative conduct complained about, certain attention has also been given to lawfulness. The incumbent ombudsman, Alex Brenninkmeijer, emphasises the relevance of mediation and interaction between administration and citizens. $^{15}$

Mediation in the conditions of leading UK public-sector ombudsmen (the Parliamentary and Health Services Ombudsman and Local Government Ombudsmen) is not very common. The ombudsmen here adopt an almost exclusively investigative approach to assess complaints. Nonetheless, one of the Local Government Ombudsmen (office in Coventry, UK) inter alia specialises in the issue of mediation. According to Ann Abraham, incumbent Parliamentary Ombudsman, the core function of her office is investigating and resolving complaints as effectively and efficiently as possible. ${ }^{16}$ Thus she underlines her investigating function.

\section{Lawfulness and standards of good administration in the Netherlands and in the UK}

\section{Lawfulness and propriety in the Netherlands}

Since 2005, propriety - "behoorlijkheid" - has received renewed attention of the Dutch ombudsmen. Reading the history of this issue in the parliamentary documents on the bill for a complaints act and in the limited number of publications of

15 E.g. Annual Report 2010. Reports of the Dutch National Ombudsman can be consulted and accessed at his Internet site, http://www.nationaleombudsman.nl/rapporten (last accessed 6 June 2011).

16 Ombudsman consults on principles of good administration, Press release 04/06, 19 October 2006. 
the last 15 years leaves the impression of a somewhat arduous development of relations between the law and propriety. Parliamentary documents at the basis of the Complaints chapter (9) of the General Administrative Law Act (GALA) maintain the position that it is up to the ombudsman to determine the content of "propriety". ${ }^{7}$

An explanation of this fact may be that the development of general principles of proper administration is built on the basis of the development of administrative law in the Netherlands, and this development has been moulded by the courts. The legislator has followed that development, and the GALA in its current shape is the product of more than 100 years of jurisprudence. Seen from that perspective, propriety is ingrained in Dutch administrative law, and it would not seem necessary to make a distinction between legal norms and norms of propriety, between the law and (public-administration) ethical norms. In Dutch positive administrative law, scholars apparently do not feel the need to evaluate that distinction..$^{18}$ From the perspective of propriety, an ombudsman cannot give a binding judgement on the legal relation between administration and a citizen in conflict, but for the assessment of the situation, the applicability of the law is important in giving guidance to constituting propriety. For the National Ombudsman's office, the distinction between lawfulness and propriety is part of a long standing practice. ${ }^{19}$

For the courts in the Netherlands, whether ordinary or administrative, the ombudsman reports and the requirements of proper administration are a separate reality compared with the vast body of administrative law in terms of legal rules and jurisprudence. The courts do recognise the ombudsmen's function, but they give their own judgements anyway. The competences of public-service ombudsmen and of the courts are separated. In general, an ombudsman cannot investigate administrative decisions where appeal to a court is pending or where an administrative court has given judgement. Nonetheless, in judgements, a reference to the ombudsman in the scheme of legal protection is often considered. In a case where legal aid had been refused to the complainant in order to get legal assistance to file a complaint with the National Ombudsman, the courts said:

Filing a complaint with the National Ombudsman ... can be done by filling out an electronic form or by writing a letter to the

17 See for example: Parliamentary documents TK 2002-2003, 28747, nr. 3, p. 17 (TK= Lower House of Dutch Parliament); Propriety as a norm for evaluation by ombudsmen is prescribed by article 9:27 GALA. Also see the Parliamentary documents on the discussion about the evaluation of the office of the National Ombudsman in 1997 (Berge, ten, Gerrits-Janssens and Widdershoven 1997), TK 1997-1998, 25 650, Ontwikkeling van het instituut Nationale ombudsman.

18 Konijnenbelt refers to this debate but indicates his indifference in this matter: "For legal practice it is only of little importance to qualify general principles as legal rules or as ethical principles; they are legally in force and that is what it is all about [translation by the authors]" (Van Wijk and Konijnenbelt 1991, 71-72). Also Wiarda is not very much involved, see Wiarda 1999 61-70; Also Ten Berge and Michiels (2001, 42), however, do make the distinction between demands of propriety and the general principles of proper administration.

19 Annual reports of the National Ombudsman 1987-2003. 
National Ombudsman. Appellant can describe what her complaint was about... Filing a complaint with the ombudsman is judicially not so complicated that assistance of a legal representative would be necessary. ${ }^{20}$

In principle, ombudsman reports are accepted as evidence in courts proceedings, but they are assessed only as part of the investigation by the court, because the court checks if the investigation of the ombudsman covers the same subject matter as that of the courts. In civil claims cases, therefore, it may be a good strategy to file a complaint with an ombudsman first and then use the evidence thus gathered in civil-court proceedings for damages (see Langbroek 2007).

An official site of judiciary in the Netherlands, www.rechtspraak.nl, includes inter alia a database of judgements of the Dutch courts that are considered interesting by judges. This database includes decisions of different courts since 1995. When reviewing these decisions, we were able to find 438 cases where the word "ombudsman" is mentioned. Furthermore, the website of the Council of State (Raad van State), www.raadvanstate.nl, includes a database of its judgements and in more than 151 cases these judgements refer to the word "ombudsman". These are not representative numbers as www.rechtspraak.nl only presents cases considered interesting by judges, but it shows that reference to an ombudsman or an ombudsman's report is not uncommon in court proceedings.

\section{Lawfulness and maladministration causing injustice in the United Kingdom}

Before we start discussing the possible applicability of our general scheme in the conditions of the UK, we need to mention shortly some issues that may lead us astray or the issues that are different from those applicable in the conditions of the Netherlands. The UK ombudsmen investigate whether administrative behaviour includes "maladministration causing injustice".

The first issue to mention is the central notion of the ombudsman system in the UK - maladministration. Maladministration as such is not defined in any legal statute on ombudsmen. It is not included in the 1974 Local Government Act, nor in the 1967 Parliamentary Commissioner Act or in any other legal statute. What maladministration actually means is left for the ombudsman to decide, i.e. it is within his or her discretion to deal with this matter. And although there is a list of general examples which was given by Richard Crossman $\mathrm{MP}^{21}$ and later endorsed by Lord

20 Judicial Division of the Council of State, 201005188/1/H2, 19 January 2011.

21 In the words of Richard Crossman "maladministration includes bias, neglect, inattention, delay, incompetence, inaptitude, perversity, turpitude, arbitrariness and so on". This forms the socalled Crossman's catalogue. 
Denning in the Bradford case ${ }^{22}$, it is for the particular ombudsman to decide what actually constitutes maladministration in an individual case. The incumbent Parliamentary Ombudsman Ms Ann Abraham adopted another approach. She has not tried to define maladministration. Conversely, she has offered her opinion on the counterpart of maladministration - good administration.

Maladministration is connected with the second important point, which is a strict separation of the powers between English courts that decide on the legality of administrative action and ombudsmen that decide whether there is maladministration in administrative action, and particular respect for their mutual competences and the boundaries between them. British ombudsmen do not try to decide on the issues of lawfulness, and courts stay out of the issues of maladministration. They are very reluctant to overstep this thin line between them. In some reports of ombudsmen (Parliamentary ombudsman UK 2005, para. 132, 21; 2008, para. 107 and 391) and in a number of courts decisions ${ }^{23}$, this division of powers and the reluctance to decide or to approach the matters outside their own remit is indeed noticeable. However, maladministration may include behaviour that is not in accordance with the law, i.e. is unlawful, but it may also include the behaviour of administrative bodies that is only directly connected to their administrative functions and administration as such.

The third point that is necessary to mention is the issue of injustice. Like the term maladministration, injustice is not defined by the legal statutes, and it is left to the ombudsman to determine it. Richard Crossman MP said in this context that the Government had not tried to define injustice by using such terms as "loss" or "damage" because they might have legal overtones which could be held to exclude one thing which he was particularly anxious should remain, and that was the sense of outrage caused by unfair or incompetent administration. ${ }^{24}$ In the case of the Local Government Ombudsman, injustice in consequence of maladministration also has to be "sufficient". Last but not least there has to be a connection between maladministration and injustice, i.e. injustice has to be caused as a consequence of maladministration.

In the UK, ombudsman reports could also be a part of court proceedings. On rare occasions, ombudsman's decisions have been challenged in court proceedings by the administrative bodies or by discontent complainants. So far, a separate remit of English ombudsmen has been upheld by the English courts, meaning that as a

22 Maladministration includes inter alia "faulty administration or inefficient or improper management of affairs, especially public affairs." See $R v$ Local Commissioner for Administration for the North and East Area of England ex parte Bradford Metropolitan City Council [1979] 2 All ER 881.

23 See for example Lord Denning in R v Local Commissioner for Administration, ex p Bradford Metropolitan City Council or Lord Woolfe in R v Commissioner for Local Administration, ex $\mathrm{p}$ Croydon London Borough Council.

24 See Parliamentary Commissioner bill (Hansard, 18 October 1966 vol 734 cc42-172). 
matter of law, public bodies are not entitled to dismiss the findings of an ombudsman without good reason (Kirkham, Thompson and Buck 2008).

\section{Applicability of the lawfulness/good-administration scheme in the Netherlands and in the UK}

In the following paragraph, we illustrate the application of our general scheme to reports and results of investigations of the National Ombudsman (NL) and of the Parliamentary Ombudsman (UK). We try to find examples that confirm or refute the applicability of our scheme. In this context, we have researched collections of reports of both ombudsmen. We considered only those reports that are actually published on the Internet sites of said ombudsmen (www.nationaleombudsman.nl and www.ombudsman.org.uk) and that were adopted between 1 January 2005 and 1 June 2011. In this context, we have faced some problems, especially regarding access to the collections of reports. While the reports of the National Ombudsman are publicly accessible, since the Dutch law requires the ombudsmen to publish them, the reports of the Parliamentary Ombudsman are not publicly accessible as the law does not make their publication possible, albeit with some minor exceptions. However, the Internet site of the Parliamentary Ombudsman contains a handful of "special reports" 25 and digests of cases that describe application of Principles of Good Administration of the Parliamentary Ombudsman. ${ }^{26}$ Simultaneously, we have based our choices of the cases on our previous research into the reports of said ombudsmen. ${ }^{27}$

\section{a) Lawful and proper administrative conduct (NL)}

In these cases, the National Ombudsman concludes that the administration has acted lawfully and properly. Legal norms and norms of propriety coincide here.

In Report 2006/103, a taxpayer complained that her request to correct the taxable income for the year 2000 has been rejected by the Taxation Service. In 2004, it also rejected her request to apply the hardship clause. The reason of this rejection is that the complainant purchased a life annuity in 2001. The complainant expected to be able to reduce her taxable income for the year 2000 with the amount paid in

25 A special report is a report that is submitted to British Parliament and if Parliament decides so, it is subsequently published. The reasons for its submitting to Parliament are included in the 1967 Act on Parliamentary Commissioner for Administration.

26 The number of cases published at the Internet site of the Parliamentary Ombudsman was more than 120 case reports at the time of the writing of this paper.

27 In this context, Philip Langbroek has done a broad research of norms of the National Ombudsman with Peter Rijpkema that in the end has resulted in the renovation of the list of requirements of proper administration (Ombudsprudentie, Bju Den Haag 2005) and has been adopted (with certain changes) by the National Ombudsman, Milan Remac does a comparative study into the relations between ombudsmen and courts in connection with their use of legal norms and norms of good administration. 
2001 for the life annuity. The Taxation Service stated that such a reduction was not possible, since the complainant should have requested it with her tax declaration for the year 2000. She had not done that. The National Ombudsman assessed her complaint and evaluated the behaviour of the taxation service as not adhering to the requirement of legal certainty.

The requirement of legal certainty means that legitimate expectations of citizens and organisations from administrative bodies are observed by these administrative bodies. This requirement implies that the Taxation Service should have granted the requested reduction of taxable income if the law offers that possibility or if legitimate expectations have been raised with complainant that a reduction could be granted. ${ }^{28}$

In this case, the ombudsman considered carefully which legal rules were applicable to complainant's case and concluded that the Taxation Service had no other choice than to decide as it did. The National Ombudsman stated that the fact that the Taxation Service asked for specific information from the complainant did not make any difference. The complainant also did not assert other reasons that could justify a deviation from the rules. Therefore there was no ground for legitimate expectations concerning a reduction of her taxable income. The National Ombudsman concluded that the complaint was not justified. The action of the Taxation Service in this case was lawful and proper.

\section{b) Lawful conduct without maladministration (UK)}

It is not very common that the Parliamentary Ombudsman writes an individual report in a case when the conduct of the administrative body was lawful and without maladministration. In these cases, the investigation is usually stayed, discontinued or not even started. Of course, there could be situations where ombudsmen need to underline the reasons for not beginning or staying the investigation. The Parliamentary Ombudsman investigates the cases if there is some evidence that shows that maladministration has occurred and that has led to an injustice which still has to be remedied. The Parliamentary Ombudsman has the right to determine whether to initiate, continue or discontinue an investigation. ${ }^{29}$

A case that fits this category is described in A report by the Parliamentary Ombudsman of an investigation of a complaint about the Pensions Regulator (Parliamentary ombudsman 2010) The complainant argued that the Pensions Regulator, when deciding to decline to impose a Financial Support Direction or Contribution Notice on the parent company of his former employer, failed to exercise its statutory functions properly and its discretion reasonably. The Parliamentary Ombuds-

28 Report of the National Ombudsman 2006/103.

29 Section 5 (5) of the 1967 Parliamentary Commissioner for Administration Act. 
man established the facts of the case and compared it with the general and special standards. She found that the complainant's employer had decided to liquidate a pension scheme. The law required that in a certain period the employer who had taken a voluntarily decision to liquidate a pension scheme had to inject money into the Pension fund in order to bring it up to the Minimum Funding Requirement level. In such a case, the employees also have the possibility to seek an agreement with the pension-scheme trustees. During the actual negotiations between employees and pension-scheme trustees, the trustees approached the Pension Regulator and sought its intervention. The Pension Regulator issued a decision in which it had stated that it would not be reasonable to exercise its powers. The reasons in the decision were not extensive, so the trustees required the Pension Regulator to supply the adequate reasons for its decision. The Pension Regulator provided the trustees with only summary analyses for not taking regulatory action. However the complainant continued to press the Pensions Regulator to disclose more detailed reasons for its decision. The Pension Regulator sought the consent of trustees and of corporate entities to disclose them but they had not given their consent because the information supplied would also include commercially sensitive information. This information was not disclosed. The Parliamentary Ombudsman had investigated the process that the Pensions Regulator followed, and she reached the conclusion that the Pensions Regulator was in this regard acting within its statutory powers; at the same time, she did not find maladministration in its actions (Parliamentary Commissioner 2010, para 48, 15).

\section{c) Lawful but improper administrative conduct (NL) ${ }^{30}$}

This case includes those situations where lawfulness and propriety do not coincide. Such situations are quite rare, but there are clear examples in the ombudsprudence of the Dutch National Ombudsmen. An example is Report 2010/025. It is based on a high number of complaints against the UWV, an autonomous administrative body for the implementation of social-security and labour-insurance regulations. ${ }^{31}$ The UWV had imposed fines and had filed complaints with the prosecutions office for the breach of legal rules by persons who had tried to start their "self-employment enterprise without personnel" (in Dutch: zelfstandigen zonder personeel) with support from the UWV. The inquiry of the Ombudsman showed that they had been coached by persons employed by the UWV that in many cases had not informed them adequately about the applicable rules on time of registration and in many other cases had advised them not to register their actual working hours, because they

30 In this context, see also Report of the National Ombudsman 2005/338, report of the Ombudsman of Amsterdam of 14 June 2007, RA0612820 (internship on Greenland); Ombudsman of Utrecht, 23 April 2007/DGO 07.13073 (trial costs in objection proceedings).

$31 \mathrm{UWV}$ is an autonomous administrative authority, and it is commissioned by the Ministry of Social Affairs and Employment to implement employee insurances and provide labour-market and data services. 
would be legally prohibited from starting their own business. This occurred to the detriment of persons who had started their own enterprise and who after 3-5 years not only had to pay fines and return their unemployment benefits, but in several cases also faced criminal prosecution on the accusation of fraud. The Ombudsman considered that the coaching department and the law-enforcement department of UWV had not cooperated adequately. He concluded that the law enforcement action was legal (within the literal interpretation of the applicable legislation), but it was absolutely disproportional from a propriety perspective. ${ }^{32}$

A similar case is included in Report 2006/379. Here the complainant argued that he was arrested on suspicion of theft of a parking permit at his home with an unnecessary police display. The Ombudsman carefully enquired if there was sufficient ground for suspicion of theft against the complainant. He concluded that this was indeed the case. Also other criteria for arrest without being caught in the act had been met, and therefore the arrest was lawful in principle. But that does not mean that the way in which permission was given by the prosecutor was proper. Furthermore, the Ombudsman evaluated the behaviour of the prosecutor against the requirement of proportionality, formulating the following context norm:

The requirement of proportionality means that while conducting a criminal investigation the prosecutor and the police have to choose the least burdensome method for the suspect. This involves that competences under criminal law, like arresting someone, should be exercised in moderation. The police and the prosecutions office should be alert to minimise the breach of privacy of the suspect during the procedure of arrest. ${ }^{33}$

The Ombudsman continues by searching for reasons why the suspect was not invited for questioning at the police station and has concluded that such reasons were absent in the records of the suspect. Therefore the prosecutor should have stated as a clear condition for the arrest that the suspect would not have appeared voluntarily upon invitation by the police. The behaviour of the public prosecutor therefore was indeed lawful but not proper, as it violated the requirement of proportionality. ${ }^{34}$

\section{d) Lawful conduct with maladministration (UK)}

The ombudsmen may deal with cases where administrative conduct is fully in accordance with the law, but it is not in accordance with other types of norms, espe-

32 Report 2010/025, ZZP-ers met een valse start.

33 Report 2006/379.

34 An older example is the towing-away and keeping-in-custody of a car with a broken window, without warning the owner, where the owner had to pay for the removal and the custody. This was legal according to Amsterdam district court (2 January 1992, NJ 1994, 219), but improper according to the National Ombudsman - see Report 1997/498. 
cially moral or ethical norms. Breach of these "other" norms may result in maladministration. The Parliamentary Ombudsman rarely states directly that a certain administrative behaviour was unlawful or not in accordance with the law. In most cases, she remains only in the sphere of maladministration. However the question of legality or lawfulness has been tackled in some reports where the Parliamentary Ombudsman was not able to evade actually expressing her opinion on the relation between the legality and maladministration of administrative action.

This situation is described in the report A Debt of Honour: The Ex Gratia Scheme for British Groups Interned by the Japanese during the Second World War (Parliamentary Ombudsman 2005). According to this scheme, the British groups who were interned during the Second World War by the Japanese were eligible to receive an ex-gratia payment. The complainant was born in Shanghai. His parents were British subjects. During the Second World War, he was interned by the Japanese as a British subject. According to the scheme that was announced in Parliament by a representative of the Government, one of the eligible groups was described as "British civilians who were interned", without any further qualification as to nationality or bloodline. The complainant had applied for the ex-gratia payment, but his application was rejected by the War Pensions Agency. He alleged that it was rejected because of an eligibility criterion that had been introduced only months after the scheme has been actually established. He considered that he met the eligibility criteria originally announced to Parliament as he was interned as a British subject and he is British citizen who has lived in the UK since 1946 and thus can demonstrate a direct link to the UK. The question of the legality of this scheme is interwoven within the whole report. The Parliamentary Ombudsman expressed that her role is to determine whether the administrative actions about which individuals complain constitute maladministration causing injustice to them and not the issue of the legality of such actions (Parliamentary Ombudsman 2005, para 31, 6). In the report, she accepted the fact that the legality of the ex-gratia scheme had already been considered by the courts and that they found it lawful. However, the courts' decisions on legality of the scheme have not prevented her from investigating whether those actions of the administrative authority constituted maladministration causing injustice to the complainant, i.e. maladministration falling short of unlawfulness (ibid., para 33,6). In the end, she concluded that there was maladministration which caused injustice even though the administrative action had otherwise been lawful (ibid., para 210, 31).

\section{e) Unlawful and improper administrative conduct (NL)}

This combination is very common in reports of ombudsmen where legal norms and norms of propriety can coincide. It is, for instance, included in a case of the Ombudsman of Rotterdam concerning the working methods of the so called "house visiting teams" in specific neighbourhoods in Rotterdam (Ombudsman Rotterdam 2007). The "house visiting teams" actions are done in connection with the munici- 
pal policy to enhance the liveability in problematic neighbourhoods of Rotterdam. They are supposed to deal with problems that are linked to drug-related crime, youth crime, illegal subletting of apartments, illegal immigrants and so on. At the same time, many people living in these neighbourhoods are in need of support from their housing associations and from the municipality. As a matter of policy, every year some 25,000 visits of these "house visiting teams" are being made in these neighbourhoods. They consist of inspectors of UWV (social benefits agency), a representative of the housing association, a representative of the energy company, a representative of the social services of the municipality, a bailiff to collect debts and a member of the police. Their practice is to ring the doorbell and upon opening to enter the home without asking for permission. Most people living in these neighbourhoods are immigrants, unemployed, people that generally do not know their rights, especially the right to refuse the team from entering their home. Team members would enter the bathroom, open cupboards in order to check if people were living together whilst receiving benefits or a (higher) pension for persons living as singles. Admittedly, many people were also very satisfied with the attention and help they received from such teams for solving their problems within the house or with writing applications for extra social benefits (e.g. for a new washing machine), or arranging healthcare related services. Nonetheless, the Rotterdam Ombudsman received many complaints against this practice and concluded that apart from breaches of essential defence rights under article 6 of the European Convention of Human Rights ${ }^{35}$ (prohibition of so-called "fishing" expeditions, gathering evidence without clear suspicion and without a clear specification of what law enforcement officers are looking for), there had been grave violations of privacy rights (the right to the privacy of one's home). The City of Rotterdam refused to change its policies implying breach of constitutional rights and of norms of propriety (fairness, basic rights like the right not to be convicted before proven guilty), but it should be noted that there is a coincidence of unlawfulness and propriety.

In report 2011/118, the National Ombudsman dealt with a complaint against the Taxation Service. The Taxation Service had confiscated the complainant's car. This happened after the police had arrested the driver of the car, an acquaintance of the complainant. The Taxation Services had forced the sale of the car in order to cover debts of car taxes from the complainant. The complainant informed the Taxation Service that he disagreed and asked for the car to be returned including tools and equipment that had been inside the car. The taxation service did not react to his query. In reaction to the Ombudsman inquiry, the Taxation Service admitted they had not reacted timely to the complainant's letters and that if they had done so, the forced sale of the complainant's car would not have taken place, but the Taxation Service apologised for that and offered financial compensation. However, the re-

35 In ECHR, 3 May 2001, J. B. v Switzerland, application no. 31827/96, the court holds that socalled "fishing expeditions" are not allowed; authorities are allowed to demand and enforce discovery of documents only as far as they know they exist. 
fusal to compensate for the equipment in the car that disappeared as a consequence of the car confiscation was evaluated as contrary to the requirement of reasonableness, and the Taxation Service had not lived up to the duty to make an inventory of possessions inside the confiscated car. This negligence should not work to the detriment of the position of the complainant concerning his duty to deliver evidence that the tools and the equipment had been in the car. The negligence concerning the registration of the tools in the car should be considered illegal, and the refusal to compensate for the lost equipment was considered improper because it was contrary to the requirement of reasonableness.

\section{f) Unlawful conduct with maladministration (UK)}

An unlawful administrative action usually equals maladministration. However, an ombudsman has to take into account all circumstances of the case while deciding whether unlawful behaviour of the administrative body also constitutes maladministration. Although unlawful behaviour often also includes maladministration, it is not automatically maladministration. This reflects differences between maladministration and unlawfulness. As stipulated before, an ombudsman (in the UK conditions) cannot give a binding decision that an administrative action is unlawful. But although maladministration is not always unlawful, we are looking for cases where ombudsmen proclaimed unlawful actions or actions that were not in accordance with statutory requirements as maladministration. If the Parliamentary Ombudsman deals with an administrative action which is unlawful, she can nonetheless decide the case from the position of maladministration, even though it could be questionable whether she has an obligation to find maladministration if there was a breach of law. ${ }^{36}$ And indeed, there are some statutory bars that prevent the Parliamentary Ombudsman from dealing with cases when the complainant has or had a right of appeal, reference or review to or before a tribunal or he or she has or had a remedy by way of proceedings in any court of law. ${ }^{37}$ Also, if the administrative action is unlawful, the complainant may surely protect his/her right by applying for judicial review of the decision. On the other hand, the Parliamentary Ombudsman herself refuses to decide whether the administrative decision is unlawful. She confirmed this for instance in her speech at the Society of Advanced Legal Studies in October 2005. ${ }^{38}$ Still the Parliamentary Ombudsman may circumvent these provisions as she did in the A Debt of Honour (Parliamentary Ombudsman 2005) Then it is possible that there could be a case where an unlawful administrative action is proclaimed also to be maladministrative.

36 This case will hopefully be soon decided by the senior English courts.

37 Section 5 (2) a) and section 5 (2) b) of the 1967 Parliamentary Commissioner for Administration Act. There are very similar provisions also in the 1974 Local Government Act.

38 See http://www.ombudsman.org.uk/about-us/media-centre/ombudsmans-speeches/archive/ sp2005-02. 
In a case against Jobcentre Plus and Debt Management ${ }^{39}$, the complainant argued that Jobcentre Plus had given her and her local authority inconsistent information about their decisions concerning her benefit entitlement (Parliamentary Ombudsman March 2009)..$^{40}$ The complainant also stated that Debt Management had taken $£ 895.44$ from her mortgage account without telling her and without giving her the right of appeal against that decision. (Parliamentary Ombudsman March 2009, 74). In 2003, the complainant successfully claimed income support. In December 2004, Jobcentre Plus decided that she was not entitled to income support. Jobcentre Plus did not inform the complainant about this decision. However, the decision was sent to the local authority. On the basis of information from the local authority, the complainant appealed against the decision, but her appeal was rejected on the basis that Jobcentre Plus had not formally decided about her benefit entitlement. The Parliamentary Ombudsman found out that Jobcentre Plus had failed to give the complainant proper notice of its decision and it should have given her a proper notice about the amount and period of the overpayment. It also had not informed her about the right of appeal against the decision. The Ombudsman furthermore found that Jobcentre Plus gave the complainant and her local authority inconsistent information and they unfairly refused to accept her appeal. Because of these facts, there was maladministration in the administrative actions of Jobcentre Plus concerning the complainant. Although the case does not include an express reference that the action of administrative authority was unlawful, it is possible to notice that Jobcentre Plus apparently did not follow its procedures in accordance with its statutory obligations.

\section{g) Unlawful but proper administrative conduct (NL)}

Reports stating that the administrative behaviour was unlawful but nonetheless proper are almost none-existent. If it does occur, it is in situations where an administrative body, usually the members of the police, has to operate on the edge. The Dutch legislator sometimes lends the police a helping hand. This is the case of article 2, paragraph 3 of the Act on entering private premises (Wet op het binnentreden) that states: "A written authorization for entering the premises as indicated in paragraph 1 is not required in the case of prevention or fighting serious and immediate danger for the safety of persons or goods. In such a case the premises must be entered without delay."

Without this provision, police officers, entering private premises without an authorisation while conducting their assistance duty, would maybe act in conformity with requirements of propriety, but unlawfully.

39 Jobcentre Plus is an executive agency of the Department for Work and Pensions.

40 The report Putting Things Right: is a digest of different cases, and this is one of them. The report is available at http://www.ombudsman.org.uk/improving-public-service/reports-andconsultations/reports/parliamentary/putting-things-right (last accessed 6 June 2011). 
In report 2006/073, the National Ombudsman formulated the following norm in context as a concretisation of the requirement of reasonableness:

"The requirement of reasonableness implies that the administrative body weighs the interests in the dispute against each other and that the outcome of the weighing process is not unreasonable. This means that an administrative body must deviate from compulsory legal provisions if sticking to their application would lead to a disproportionate disadvantage for the individuals involved."

Thus, it recognises the possibility that the administration violates a legal norm because of considerations of propriety.

One rare example of administrative behaviour that was evaluated as unlawful but proper can be found in Report 2006/247. The complainant argued that members of the police team had shot at him repeatedly with an illegal type of ammunition, so-called "bean bag" ammunition. The National Ombudsman considered that both bean bag ammunition and the firearm used in the police action did not belong to the legally admitted weaponry of a police squad. Thus illegal ammunition was used in the case where the complainant held several people hostage while threatening to kill them. Members of the Police team did not use legal "alive ammunition" but had decided to use illegal ammunition that did not kill the complainant but only rendered him unconscious. This was the reason why the National Ombudsman evaluated the action of the Police to use legally not permitted bean bag ammo as unlawful but justifiable and therefore proper.

This report and this analysis, however, was challenged by several Dutch administrative law scholars. They claim that "lawfulness" itself is a requirement of proper administration (Damen 2008; Schlössels 2005, 2006, 2007; see also van Montfort 2005; Horstink-von Meijenfeldt 2006). Furthermore, they claim that the unlawful/proper distinction could have been avoided by the ombudsman by applying the proportionality principle to the bean bag case (making the case fit for the "lawful and proper" category). Langbroek and Rijpkema have contested this approach, stating that an ombudsman cannot shape the law as a court can do, and they have argued for an analytical separation of legal and propriety assessments and a separation of responsibilities of courts and ombudsmen (Rijpkema and Langbroek 2008).

\section{h) Unlawful conduct without maladministration (UK)}

Similarly to the case of the Netherlands, the existence of this category the is also arguable in the UK conditions. As we have seen in the Dutch examples, these cases are not very numerous, but they exist, especially in exceptional or, so to say, threshold situations. In this context, we had anticipated that it would be probably possible also to find some rare examples in the UK conditions. 
Even though some of the reports of the Parliamentary Ombudsman were indeed published at the Internet site of her office and are accessible to the public, we were not able to collect a representative sample of the cases that would belong into this category, as the Parliamentary Ombudsman cannot publish her reports. Most of the individual decisions of the Parliamentary Ombudsman are not published due to the statutory bar that prevents her to disclose investigation reports to the general public. The investigations of the Parliamentary Ombudsman are strictly conducted in private. Because of that, it is not possible to say whether there is a case that would fit into this part of our scheme. However, those reports of the Parliamentary Ombudsman that are actually published, are the most important, the most influential and the most remarkable ones. Because of that, we can assume that if there was a case describing unlawful behaviour without maladministration, it would also have been published. And at the same time, we cannot exclude the possibility that in the future, there will be such a decision.

In the case of the Parliamentary Ombudsman, we can step a bit further. In 2001, the Parliamentary Ombudsman developed, consulted and published her Principles of Good Administration. ${ }^{41}$ The principles include 6 broad statements against which the Parliamentary Ombudsman assesses or judges the behaviour of administrative bodies. Thanks to these principles, it is possible to suggest that a situation that fits into the fourth part of the scheme can actually come true. The first of the Principles of Good Administration is the principle "Get it right", which requires that public bodies act in accordance with the law and with regard for the rights concerned. The "Get it right" principle thus positively includes a sub-principle "Get it lawful". And hence if an administrative body does not act in accordance with the statutory provisions, this may imply that the Parliamentary Ombudsman will find the breach of a principle of good administration that could in the end lead her to the decision of maladministration. The word "may" is important because a breach of one of the principles does not necessarily result in maladministration. This statement is confirmed in the report Putting Things Right: Complaints and Learning from $D W P$, which alleges that "a failure to meet one or more Principles does not necessarily indicate maladministration" (Parliamentary Ombudsman March 2009, 47), Even if the administrative authority does not act in accordance with its statutory obligations and thus not in accordance with the "Get it right", principle this does not necessarily mean that the Parliamentary Ombudsman will always find maladministration in that particular case. The Parliamentary Ombudsman needs to take into account all circumstances of every individual case.

41 The principles are applicable to the conduct of administrative bodies. The principles are broad statements of what the Parliamentary Ombudsman believes bodies within her jurisdiction should be doing to deliver good administration and good customer service. See the Consultation report for Principles of Good Administration at http://www.ombudsman.org.uk/improvingpublic-service/ombudsmansprinciples/principles-of-good-administration/consultation-reportpriciples-of-good-administration (last accessed 6 June 2011). 


\section{Analyses}

We used the previous eight examples to illustrate the applicability of our general matrix of possible combinations of normative assessments of administrative conduct. We have presumed that there are four possible combinations of administrative conduct and subsequent ombudsman's assessments. The ombudsman's work is usually connected with a different scope of control than the scope of control of national courts. The combination of these two facts may lead to the creation of a normative system of good-administration norms (propriety or principles of good administration) that partially overlaps with the system of legal norms. That was our most important presumption when applying our general scheme. We have applied our scheme to the case reports of two national ombudsmen - the Dutch National Ombudsman and the UK Parliamentary Ombudsman.

We have found out that the scheme is fully applicable in the Netherlands, as we were able to fill all the boxes in our scheme with examples. Although examples were not very numerous, we were able to discover situations where the National Ombudsman decided that the lawful behaviour of a body within his competence was not in accordance with requirements of proper administration. And even though these example were rather sporadic (and sometimes contested by administrative law scholars), it indeed confirms our presumption about a different normative system that could be created by the ombudsman. Examples that belong into the first three categories are much more numerous as they often copy or supplement legal standards. The National Ombudsman himself emphasises that the situation described in our general scheme is possible and clear (Nationale Ombudsman 2006). The situation in the UK is different, however. Although we cannot fully support our presumptions with actual examples that would fit into all boxes of our general scheme, we can present some theoretical reasons which in our opinion lead to the conclusion that "unlawful administrative action without maladministration" could also exist in the UK conditions and that it can be assessed as such by the ombudsman.

First of all, ombudsmen should cover or investigate a concept that is different to the law. That could be maladministration, good administration or proper administration etc. ${ }^{42}$ Second, these ombudsmen should be the ones who give contents to these "concepts different to the law", i.e. they should exercise their particular normative functions to fill these concepts with norms or with standards. Third, these ombudsmen have to apply their norms in a consistent manner that could be tracked

42 Obviously, we try to apply this matrix only to ombudsmen who assess administrative behaviour against the perspective of the general concept of good administration, i.e. ombudsmen of "the second wave". We do not try to apply this scheme to the oldest ombudsmen (the ones in Sweden or Finland) and to the youngest ombudsmen that deal predominantly with human-rights issues. This could be an issue for another research. For the characterisation of the second wave of the ombudsmen see, for example, Diamandouros 2007. 
down to certain norms or principles (standards). Our two ombudsman examples have met all three requirements.

At this point, we want to give a little more consideration to the fourth category (lawful conduct but not in accordance with general standards of good administration). Although this category is rather rare, in our view, it is more than possible that it could also occur in other conditions than the Dutch ones. We would like to support this argument by following considerations or reasons that are formulated in connection to the situation in the UK.

The first reason is the quality of the administrative behaviour that belongs to this category. Of course, we do not presume that the Parliamentary Ombudsman or even the National ombudsman are going to decide on a daily basis that some unlawful administrative behaviour is without maladministration or that lawful administrative conduct is not proper. However, there could be threshold situations where it is required to consider all individual circumstances of the case and decide, as in the Dutch "bean-bag" case, according to common sense.

The second reason is the difference between the contents of maladministration and propriety and unlawfulness (illegality). The distinction between these notions has been confirmed by some reports of ombudsmen and by the decisions of English and Dutch courts. ${ }^{43}$ Maladministration and propriety are the categories used almost exclusively by ombudsmen, and legality is used almost exclusively by the courts. The courts do not like to venture into the realm of maladministration or propriety, and, on the other hand, the ombudsmen only rarely decide on lawfulness. It is the ombudsman who assesses the individual circumstances of the case, and it is the ombudsman who has to decide - with great discretion - whether there has been maladministration or whether the conduct has been improper. And it is the ombudsman who decides what the maladministration or the propriety actually is. The court's assessment of legality of administrative behaviour also binds the ombudsman, but that does not mean that she or he cannot consider and evaluate the case from the different perspective. Some cases suggest that the Parliamentary Ombudsman is not afraid to assess the administrative action from the perspective of maladministration even though the legality of the case had already been considered by the court, as e.g. in the Debt of Honour case (Parliamentary ombudsman 2005). Maladministration, propriety and legality tests are divided between separate responsibilities of ombudsmen and the courts.

43 And also by the European Court of First Instance of 4 October 2006, Case T-193/04 (Tillack v. the European Commission, para. 128: "For the sake of completeness, the classification as an 'act of maladministration' by the Ombudsman does not mean, in itself, that OLAF's conduct constitutes a sufficiently serious breach of a rule of law within the meaning of the case-law. In the institution of the Ombudsman, the Treaty has given citizens of the Union, and more particularly officials and other servants of the Community, an alternative remedy to that of an action before the Community Courts in order to protect their interests. That alternative non-judicial remedy meets specific criteria and does not necessarily have the same objective as judicial proceedings (Case T-209/00 Lamberts v Ombudsman [2002] ECR II-2203, paragraph 65)." 
For the Netherlands, the relationship between the ombudsmen and the courts is not very problematic, as the ombudsman occasionally refers to jurisprudence and the courts sometimes refer to ombudsman investigations and ombudsman reports. They both carefully seek to stay within their own domains, as they do not seek the confrontation with each other.

A further consideration is that there is a partial overlap between the law and requirements of propriety. Some, but not all, legal norms also express requirements of propriety. Think of legal timeframes and the requirement of timeliness and also, for example, of the requirement of privacy which has been expressed in human rights (integrity of the body, house, privacy of correspondence). But there is hardly an ethical component in the legislative's choice to make driving on the right or on the left side of the street mandatory. As we stated in the beginning of this article, requirements of good administration also exist in their own right, they do not coincide completely with the law. As instrumental legislation has become quite dominant, it is highly probable that an occasion will develop where an ombudsman has a choice to give a judgement where unlawfulness is combined with propriety.

Finally, the ombudsmen in their assessment of administrative behaviour and qualifying it in terms of maladministration may not commit an illegal act. In the UK, judicial review of ombudsman reports is possible, and indeed, it sometimes happens. This shows that there are boundaries to an ombudsman's remit. In the Netherlands, judicial review of an ombudsman report by an ordinary court is conceivable, but, as far as we know, it has never happened. At the moment, a new case is pending before the courts in London against the maladministration qualifications in the Parliamentary Ombudsman's report on Six Lives: The Provision of Public Services to People with Learning Disabilities (Parliamentary ombudsman Session 2008-2009) Mencap, a charity with public responsibilities taking care of disabled persons, has challenged the maladministration qualifications in the report and was granted permission to judicial review. The judgement is expected in autumn 2011.

\section{Conclusion}

We have tried to show that for the work of ombudsmen in comparison to the work of courts, non-legal norms constitute an important set of standards for the evaluation of administrative behaviour when complained against. Ombudsmen in the UK and in the Netherlands have developed these standards. These norms are based on similar principles - principles of good administration. The ethical perspective of these norms provides them with the possibility of different outcomes of the evaluation of administrative behaviour compared to the legality tests used by the courts. Even so, ombudsmen's use of different standards than courts only rarely leads to outcomes that contradict legal assessments of administrative behaviour within the same context as the complaint at hand. 
In both countries, we have found examples that could fit into our general theoretical scheme. In accordance with the scheme, we underline that there could be situations where the lawfulness of administrative action is not identical with the requirements of good administration. Of course, one of the leading requirements of good administration is a conduct in accordance with the law, but we cannot say that the law and good administration are categories with equal contents. Lawful administrative action need not necessarily be the administrative action that is in accordance with requirements of good administration. This is a strong indicator that the evaluation of administrative behaviour against requirements of good administration and against the law belongs to a different domain of responsibility. However, this does not mean that ombudsmen will automatically qualify administrative behaviour as unlawful but proper or lawful but maladministrative. But they can reach that conclusion. If ombudsmen do so, there has to be an exceptional case, and they will have to assess and weigh thoroughly all circumstances of each particular case, even the possibility that an administrative body will challenge an ombudsman report in court.

That does not mean that ombudsmen should be reluctant to try to establish and subsequently use their own standards, i.e. standards different to the law. This is mostly connected with the fact that there are ombudsmen whose scope of control lies beyond the law and can be identified as maladministration or propriety (or some other ethical concept), as is the case with the Parliamentary Ombudsman in the UK or the National Ombudsman in the Netherlands. Ombudsmen are not courts, and thus their assessment of the situation has to fit their own perception of administrative justice.

However that may be, by assembling the normative experiences of ombudsmen as laid down in their reports, developing a bottom-up code of ethics for public administration, starting from specific context-bound good-administration requirements becomes a good possibility. Its advantage is that first the norms applied are general requirements of good administration; second that the application and therefore the meaning of these norms in specific situations (e.g. pensions, housing, policing, health insurance etc.) can be clarified and explained by means of analysis of ombudsman reports. This presupposes that ombudsmen do not shy away from mentioning and defining the norms they use when evaluating administrative behaviour. Another necessity is that the results of their investigations are published in the way the courts publish their decisions. There could be certain legal bars on publishing their reports, but their publication (even in a limited way) may lead to a strengthening of the ombudsman's standards, it can enhance their applicability, and, last but not least, it may give a transparent overview of ombudsmen's methods.

By defining and developing these norms, ombudsmen do not try to create an entirely new normative system. The fact is that they derive these norms from the legal system and from the system of values applicable to citizen-administration rela- 
tions. Ombudsmen only identify them and shape them so that these norms reflect their perception of good administration within the particular time period. Because of this, it would be adequate if there was a broader discussion about the difference between the law and ethical norms like maladministration and propriety, and about their applicability to particular situations. Another question is in how far the ombudsman's evaluations of administrative conduct are accepted, rejected or ignored by the courts by administrative bodies and by the parliaments that appointed them.

An unambiguous fact is that any situation complained about can be perceived differently through the eyes of the ombudsman and through the eyes of the judge. In this article, we have tried to show that even though the ombudsmen sometimes use a different standard than the law that they sometimes assess a situation differently than the courts, ultimately they walk towards the same goal - offering an independent evaluation of a situation involving public administration and citizens and the enhancement of administrative justice.

\section{References}

Annual Report of the National Ombudsman 2007. 2010. "Regel is regel is niet genoeg." Nationale Ombudsman. Den Haag 2010.

Aubert, Vilhelm. 1967. "Courts and Conflict Resolution." The Journal of Conflict Resolution 11 (1), 40-51.

Berge, J. B. J. M. ten, M. P. Gerrits-Janssens and R. J. G. M. Widdershoven. 1997. Blik op de toekomst van de Nationale ombudsman. Deventer: Kluwer.

Berge, J. B. J. M. ten and Philip M. Langbroek. 2005. “The Surplus Value of the Ombudsman.” In Hans Gammeltoft-Hansen and Jens Olsen (eds). The Danish Ombudsman 2005. Copenhagen: The Danish Ombudsman, 113-140.

Berge, J. B. J. M. ten and F. C. M. A. Michiels. 2001. Besturen door de overheid. Deventer: Kluwer.

Brenninkmeijer, Alex. 2007. "Fair Governance: A Question of Lawfulness and Proper Conduct." Van Slingelandt lecture. Translation of Alex Brenninkmeijer. 2007. "Eerlijk bestuur: Over rechtmatigheid en behoorlijkheid." Van Slingelandt lezing. BESTUURSKUNDE 2007-1.

Damen, L. J. A. 2008. "Behoorlijk, en ook rechtmatig, of juist eerlijk?" NTB 2008 (2), 40-51.

DeLeeuw, Magdalena E. 2009. "An Empirical Study into the Norms of Good Administration as Operated by the European Ombudsman in the Field of Tenders." EUI Working Papers, RCAS 2009/20. Available at http://cadmus.eui. eu/bitstream/handle/1814/11234/EUI_RSCAS_2009_20.pdf? sequence=3 (last accessed 12 November 2011). 
Diamandouros, Nikiforos. 2007. "Legality and Good Administration: Is there a Difference?" Speech by the European Ombudsman, the Sixth Seminar of National Ombudsmen of EU Member States and Candidate Countries on "Rethinking Good Administration in the European Union." Strasbourg, France, 15 October.

Drewry, Gavin. 2009. "Ombudsmen and Administrative Law: Bright Stars in a Parallel Universe?” 17 Asia Pac. L. Rev. 3, 3-26.

Finkelstein, Elad and Shahar Lifshitz. Finkelstein, Elad and Lifshitz, Shahar, Bargaining in the Shadow of the Mediator: A Communitarian Theory of PostMediation Contracts (2 July 2010). Bar Ilan Univ. Pub Law Working Paper No. 10-10. Available at SSRN: http://ssrn.com/abstract=1633744 (last accessed 12 November 2011).

Gemeentelijke ombudsman Rotterdam, Baas in Eigen Huis, 2 November 2007. See: $\quad$ www.ombudsman.rotterdam.nl/publicaties/Eindrapport\%20Baas\%20 in\%20eigen\%20Huis.pdf.

Gemeentelijke ombudsman Rotterdam, Annual report 2006.

Gemeentelijke ombudsman Rotterdam, Annual report 2005.

Gemeentelijke ombudsman Utrecht, Annual report 2006.

Gunning, Isabelle R. 2004. "Know Justice, Know Peace." Cardozo Journal of Conflict Resolution Vol 5 (2), 87-95.

Heede, K. 2000. Control and Redress at Union Level: The European Ombudsman. Deventer: Kluwer Law International.

Horstink-von Meijenfeldt, S. J. 2006. "De aanvullende rechtsbescherming van de Nationale ombudsman." JB-plus 1, 31 March.

Kirkham, Richard, Brian Thompson and Trevor Buck. 2008. "When Putting Things Right Goes Wrong: Enforcing the Recommendations of the Ombudsman." Public Law Autumn 2008, 510-530.

Kucsko-Stadlmayer, Gabriele. 2008. European Ombudsman-Institutions: A Comparative Legal Analysis Regarding the Multifaceted Realisation of an Idea. Vienna: Springer.

Kudrycka, B. 1997. "Elaboration of Legal Principles of Proper Administration in Poland." In Bart Hessel and Piotr Hofmanski (eds). Government Policy and Rule of Law. Białystok: Universytet w Bialymstoku, 61-81.

Langbroek, P. M. 2007. "Ombudsmanwerk tussen overheid en burger." Ars Aequi 2007, 910-920. 
Langbroek, P. M. 1997. “General Principles of Proper Administration in Dutch Administrative Law." In Bart Hessel and Piotr Hofmanski (eds). Government Policy and Rule of Law. Białystok: Universytet w Bialymstoku, 81-107.

Langbroek, P. M. and P. P. Rijpkema. 2006. "Demands of Proper Administrative Conduct: A Research Project into the Ombudsprudence of the Dutch National Ombudsman." Utrecht Law Review 2 (2), 81-98. Available at www.utrechtlawreview.org (last accessed 12 November 2011).

Langbroek, P. M. and P. P. Rijpkema. 2004 Ombudsprudentie, over de behoorlijkheidsnorm en zijn toepassing, BJU, Den Haag.

Meyerson, Bruce E. 2005-2006. "The Dispute Resolution Profession Should not Celebrate the Vanishing Trial." Cardozo Journal of Conflict Resolution vol. 7 (1), 77-82.

Montfort, A. J. G. M. van 2005. "Klachtvoorzieningen." In L. J. A. Damen et al. Bestuursrecht, rechtsbescherming tegen de overheid, bestuursprocesrecht. Den Haag: BJU, Nationale Ombudsman, Jaarverslag 2006.

Nationale Ombudsman, Jaarverslag 2007.

Nolan Haly, Jaqueline M. 2005. "The Merger of Law and Mediation: Lessons from Equity Jurisprudence and Roscoe Pound." Cardozo Journal of Conflict Resolution 6 (1), 57-72.

Parliamentary Ombudsman UK, Principles of Good Administration: Response to Consultation. March.

Parliamentary Ombudsman UK. 2005. A Debt of Honour: the ex gratia scheme for British Groups interned by the Japanese during the Second World War. July.

Parliamentary Ombudsman UK. 2007. Equitable Life: a decade of regulatory failure, special report, 16 July 2008.

Parliamentary Ombudsman UK, Six Lives: the provision of public services to people with learning disabilities. Session 2008-2009. Available at http://www. ombudsman.org.uk/improving-public-service/reports-and-consultations/ reports/health/six-lives-the-provision-of-public-services-to-people-withlearning-disabilities/1 (last accessed 6 June 2011).

Parliamentary Ombudsman UK, Putting things right: Complaints and learning from DWP, March 2009.

Parliamentary Ombudsman UK, A report by the Parliamentary Ombudsman of an investigation of a complaint about the Pensions Regulator, June 2010.

Rijpkema P. P. (ed.). 2003. Grondslagen van het recht. BJU, Den Haag: Achtergronden. 
Rijpkema, P. P. and P. M. Langbroek. 2008. "Behoorlijk onrechtmatig, over de aard van de behoorlijkheidstoetsing." Nederlands Tijdschrift voor Bestuursrecht 33, 253-259.

Schlössels, R. J. N. 2007. “Kroniek beginselen van behoorlijk bestuur.” NTB 2007, 6.

Schlössels, R. J. N. 2006. “Kroniek beginselen van behoorlijk bestuur." NTB 2006, 50.

Schlössels, R. J. N. 2005. “Kroniek beginselen van behoorlijk bestuur." NTB 2005, 33.

Stulberg, Joseph B.. 2004-2005. "Mediation and Justice: What Standards Govern." Cardozo Journal of Conflict Resolution 6 (2), 213-245.

Van Wijk, H. D. and Willem Konijnenbelt. 1991.... Hoofdstukken van Administratief recht. Utrecht: LemmaVUGA.

Wiarda, G. J. 1999. "3 typen van rechtsvinding" in de bewerking van T. Koopmans. Deventer: Kluwer. 